\title{
Supply and demand for antimalarial drugs and diagnostic testing in the era of subsidies: multi-country findings
}

Tanya Shewchuk

From Challenges in malaria research

Basel, Switzerland. 10-12 October 2012

Abstract not submitted

Published: 15 October 2012

doi:10.1186/1475-2875-11-S1-015

Cite this article as: Shewchuk: Supply and demand for antimalarial drugs and diagnostic testing in the era of subsidies: multi-country

findings. Malaria Journal 2012 11(Suppl 1):015.

Submit your next manuscript to BioMed Central and take full advantage of:

- Convenient online submission

- Thorough peer review

- No space constraints or color figure charges

- Immediate publication on acceptance

- Inclusion in PubMed, CAS, Scopus and Google Scholar

- Research which is freely available for redistribution 